\title{
THE PROBLEMS OF COORDINATION AND COOPERATION OF THE BRACHES OF TRANSPORT COMPLEX IN UKRAINIAN SSR (1970-1980)
}

\author{
Anatoliy Gorban \\ hetman Petro Konashevicha-Sahaydachnyi Kyiv State Maritime Academy \\ 9 Kyrilovska str., Kyiv, Ukraine, 04211 \\ feclo15@gmail.com
}

\begin{abstract}
In the presented article the level of activity and coordination of Ukrainian SSR transport branches in 1970-1980-s is considered on the basis of archives and scientific literature. The author comes to a conclusion that under condition of general growth of transportation the lack of proper coordination of different kinds of transport and department non-coordination had their negative influence on the transportation organization in that period. First of all it was relative to the problems of general motor transport usage, transport expedition service, irrational transportation by the railway transport, economic stimulation of co-operating transport enterprise workers for their common work results. The effectiveness of measures on their coordination stayed low.
\end{abstract}

Keywords: transport, coordination, transportation, switching load.

\section{Introduction}

In 1970-1980 the transport complex of Ukrainian SSR supported the steady work of industry, building, agricultural economy, trade and service sphere, transport-economic connections between the economic regions of republic and USSR, export-import connections were realized.

But since the second half of 1970 the tempos of increase of transportations volumes were significantly decelerated, the defects and miscounts in coordination and interaction of the different types of transport, general organization of transport work and extensive way of development of the transport system of republic became more and more essential. The results of it were manifested first of all in the decrease of productivity of transport and increase of transport price cost, so conditioned the search for the new ways for raising the effectiveness of the work of all transport system links. The complications of that time were considerably consonant with the modern ones that actualized a necessity of comprehensive study of historical experience of the solution of problems of improvement of coordination and coherence of the whole transport complex.

\section{Aim and tasks of research}

For sufficient explanation of the main aims the following tasks were set:

1. Determination of the features of coordination and interaction of the different transport types of Ukrainian SSR.

2. To define the main problems of coordination that attended the Ukrainian transport complex in 1970-1980.

3. To assess the effectiveness of realization of arrangements on coordination and rationalization of transportation in 1970-1980.

4. To give recommendations about how the experience of past years can be used today.

\section{Analysis of researches and publications}

The problems of coordination and interaction of the different transport types in Ukrainian SSR in aforesaid chronological frames were not studied integrally but were limited to the only fragmental mentions in the works of separate authors. Especially the authors of the works [1, 2] considered this topic, elucidating the general state of transportation. The problems of improvement of coordination of the work of railway and motor transport in the points of their interaction were studied by the author [3], river transport - by the author [4], and in the work [5].

We analyzed the scientific studies of these authors, they are named in references. 


\section{Results of research}

Considering the problems of coordination of the work of different transport types, inherent to the transport complex, we can conventionally separate the following levels:

- distribution of loads by the transport types and rationalization of the load transportations;

- organization of the system of complex transport-expeditionary service of consigners and consignees of the loads not depending on transport type and departmental appliance.

The feature of functioning of the transport complex of Ukrainian SSR was the fact that it was not a unitary organizational system as opposite to the other branches. Transport was subordinated to the different ministries and union, union-republic, republic and local departments. That is why it was extremely difficult to realize the switching of loads and to organize the mixed transportations. The serious problems appeared also because the technical equipment of stations and meeting-points lagged behind the growth of load circulation that complicated the work and worsened the interaction of different types of arterial transport with industrial railway and departmental motor transport.

The most complicated was the problem of interaction first of all of the motor transport with different transport types, caused by the low specific weight of motor transport of general use and departmental scattering of the motor fund. Specific weight of the motor transport of general use in the work of motor transport of national economy in 1970 was by tones $21,7 \%$ and by load circulation $-24,4 \%$, against respectively $32,3 \%$ and $34,2 \%$ in 1965 . The motors were allotted with interruptions, motor transport came to the work for 11-12 hours, it was not allotted at all for several days. This practice was especially typical for Ivano-Frankovsk regional motor transport, where the work of regional motor supply failed almost every day because of failure to give motor transport [6].

The trucks fund was shortened by $16,4 \%$ and was 96,1 thousand whereas the departmental trucks fund (without collective farms) increased by 89,9 thousand units or by $39,1 \%$. The most absolute shortening of fund of the trucks of general use in 1971 in comparison with 1966 took place in Odessa region - by 1,1 thousand, Vinnitsa - 0,8 thousand, Dnipropetrovsk - 0,8 thousand, Cherkassy $-0,7$ thousand, Khmelnitsky - 0,6 thousand and Zaporizhzhya - 0,6 thousand motors [7].

Amortization of trucks left behind their supply - in 1975 48,6 thousand were amortized and only 38,9 thousand units were received. For the 1 of January, 1976 almost half $-49,2 \%$ of trucks was in operation for a long time - more than 7 years [8].

The general volume of irrational transportations remained high. The analysis of transportations by the motor transport demonstrated that the main mass of products was transported to the distance from 50 to 400 and more than $500 \mathrm{~km}$. The railways transported goods and constructions of practically whole nomenclature for industrial, housing-civil and agricultural building, transport, energetic and engineer constructions. In fact the mean radius of transportations was $350-370 \mathrm{~km}$, including less than $50 \mathrm{~km}-2,1 \%$ and more than $500 \mathrm{~km}-22,1 \%$ [1].

The one Odessa department transported near 900 thousand tons of loads to the distance less than $50 \mathrm{~km}$ annually. These irrational transportations needed 18 thousand vans including more than half of covered ones. But the leaders of Odessa regional motor administration neglected the state interest and took from railway transport mainly "profitable" transportations to the distance $200 \mathrm{~km}$ and more. In this motor administration in 1980 the transportations that were not typical for it increased and the internal regional ones - decreased by $17 \%$ [9].

The one more problem was the increase of irrational excessively far motor transportations in inter-regional and inter-republic communications [10]. Thus, the far transportations (more than $500 \mathrm{~km}$ ) by Ukrainian agro-building of Ukrainian SSR, Ministry of road building of Ukrainian SSR, Ministry of water economy of Ukrainian SSR were 30-50\% of the general volume of railway transportations of these ministries and departments. The one of causes of such situation was the departmental disintegration and absence of coordination in the work of enterprises-producers. Thus, for example, the production of 344 enterprises of industry of nonmetallic building materials, subordinated to 33 ministries and departments was received by more than 5 thousand consumers. The irrational transportation appeared at realization of transport-economic connections and in the result of it the additional ineffective transport work was carried out and it was assessed in the volume of 9 billion ton/km with expenses over 4 billion crb per year [1]. 
The imperfection of transport-expeditionary service was a significant problem. For that time in Ukraine was certain experience of functioning of transport-expeditionary enterprises - main executive structures of the management of interdepartmental connections and cooperation in transport complex. They provided the complex transport-expeditionary service in the big transport junctions, rational distribution of flows by the transport types, organization of intercity motor transportations [10].

For the strengthening of coordination of transportations were used the organizational arrangements, directed on improvement of the system of management of transport branches. In 1963 in republic were created 15 junction offices of transport-expeditionary agency (OTEA) and 6 offices of transport-expeditionary operations (OTEO). OTEA of the 1 group were created in the cities Kyiv, Donetsk, Dnipropetrovsk, Lviv, Kharkiv, Odessa; II group - in Vinnitsa, Zhitomir, Zaporizhzhya, Luhansk, Mikolaiv, Poltava, Chernigov regions; III group - in Kherson region. OTEO of the I group started to work in Cherkassy region, II group - in Kirovograd, Rivne, Ternopil, Khmelnitsky region. III group in Chernyvtsy, Zacarpathya, Ivano-Frankivks and Volynska regions [11].

They were completely responsible for the transport-expeditionary service of at centralized transportations of loads by the motor transport from railway stations, river and airports and also for the provision of population with all types of transport services. For the first year of work the plan of loads transportations on railway stations, river and airports was realized in full by administration for $94,8 \%$, not transported - 1323 thousand tons, actually transported - 23033 thousand tons. Plan was failed by: Khmelnitska OTEA - for 62 thousand tons because of untimely transfer of railway stations to OTEO service from railways. Because of untimely schedule of supply of motors by motor funds, insufficient number of loading-unloading mechanisms and loaders took place the overtime stoppage of motor transport on railways and ports for 264,4 hours and stoppages of consignors and consignees - 365,8 hours. Totally in 1963 were sent 2492,24 thousand tons of load of intercity communication. The number of sendings was 427587 [11].

TEE solved the problems of the rational distribution of transportations between the different transport types that gave more effective use of existent transport resources of Ukrainian SSR and railway stations were released of the work with numerous clients. TEE serviced the enterprises and organizations with transportation volume $58 \mathrm{mln}$ tons per year including $47,6 \mathrm{mln}$ tons by railway stations. In 1978 the central transportations were carried out at 209 railway stations, 17 river, 9 sea and 18 airports. TEE received near $13 \mathrm{mln}$ crb of profit per year, most part of it came to the local budgets [12].

In 1979 the total volume of intercity transportations by the motor transport of general use reached $32,5 \mathrm{mln}$ tons including the ones realized by transport-expeditionary enterprises $-6,5 \mathrm{mln}$ tons. According to the regular schedules $-3,6 \mathrm{mln}$ tons $-56 \%$. Starting from 1980 the intercity transportations of loads were realized according to the regular schedules, except off-clearance loads and loads of special purpose. For example in the first quarter of 1980 the volume of intercity transportations, realized by TEE, was $1,5 \mathrm{mln}$ tons, among them 997 thousand tons or $66,5 \%$ - according to the regular schedules. But the part of intercity transportations was realized by the departmental motor transport. In 1979 the number of runs, realized by departmental motor transport according to the route letters of old form was 98,7 thousand or $19,9 \%$ of all intercity runs of the Ministry of motor transport [13].

For improvement of interaction between the different transport types, the raise of quality of transport-expeditionary service of republic economy, the objective complex scientific-technical program "Transport" that must provide the development and improvement of transport system, organization of rational transportation of the loads was elaborated and accepted by the directive of Ministry Council of Ukrainian SSR of 11 of July, 1986. Its realization allowed increase centralized transportations by $13,2 \%$, and the volumes of container transportations - by $12,2 \%$ [14].

The switching of irrational transportations of the loads was urgent for unloading of transport net, especially railways. It was favored by the fact that the different transport types had practical experience of common work, and the mixed transportations of loads became spread. Thus, the especially close cooperation must be established between the motor transport enterprises and Ukrainian railways, first of all Southern-Western one. Most motor roads in Ukraine were placed in parallel with the main railway districts and were in direct closeness with them that was comfort- 
able in the aspect of coordination of railway and motor transport workers [2]. Altogether the motor transport of general use of republic realized the centralized transportations of loads that came through 70 railway stations.

In 1970 at railway stations were received and sent 1,56 billion tons of different loads. Among them near $10 \%$ were processed at places of general use that is received and sent from the railway transport to the motor one [3]. Thus, in the result of transfer of small consignments in containers (between Bila Tserkva and Kyiv) from the railway to motor transport, the cost of transportation of 1ton of load decreased from $9-10,5$ to $3,5-6,5 \mathrm{crb}$ and the delivery terms were shortened from $3-4$ days to $5-6$ hours [15].

Taking into account the overload of railway transport and also the fact that the main river artery - Dnipro had the reserve of carrying capacity, there appeared a question about the switching of many types of loads from the railway transport to the river one, widening of transportation geography, increase of load on the river fleet in less strained directions [4]. It was profitable because the price cost of transportation by the river transport was on average by $11 \%$ lower than by the railway one [15]. In this connection it was expedient to build the river wharf for many enterprises, placed along Dnipro that was proved by the technical-economic studies [5].

In 1981-1982 from railway transport to the motor and river ones were switched $5 \mathrm{mln}$ tons of important loads for which transportation by railway would be necessary 90 thousand vans [16].

The general problem that complicated the coordination of work of different transport types in republic was the different level of their subordination - Ministry of railways of USSR and Ministry of motor transport of Ukrainian SSR. At the same time almost all industrial enterprises and organization of different union, union-republic and local ministries and departments had the motor transport. As a result each type of transport had the own systems of transportation planning, statutes and legal regulations. At the beginning of 1970 years the State plan of Ukrainian SSR planned the development of motor transport of such ministries and departments, which material-technique supply was realized through the Ministry Council of republic. Most transportations of motor transport were planned by the union and union-republic ministries [3]. It complicated the coordination of work of the railway and motor transport and also regulation of their economic and legal relations.

In its turn the railways of republic often carried out organizational-technical arrangements without taking into account the possibilities of motor transport and without proper coordination of these arrangements, having proceeded from departmental interests. Thus, at the beginning of 1970 on railways were realized certain arrangements, directed on concentration of loading work at supporting stations that provided organization of these stations, concentration of loading operations at them and closure of series of stations with small volume of loading work. But they were not supported by the proper development of the load economy and the net of local motor roads. Because of these causes only $43 \%$ of supporting stations were included in transport-expeditionary service with centralized removal of loads by the motor transport of the Ministry of motor transport of Ukrainian SSR. From the other stations the load was removed by the departmental motor transport.

The volumes of switchings and mixed transportations by the river transport were small comparing with motor one that was conditioned by insufficient number of ports that generated complications in organization of their common work with surface transport types [10]. And even the work of Central river fleet of Ukrainian SSR on involvement of loads to the transportation in mixed railway-water communication was not sufficiently active and had not the proper contact with railway administration [16].

Already at the beginning of 1970 years railways annually failed to give to the river transport over than 27 thousand vans to the reloading points. Generally non-productive expenditures for fleet were $5,1 \mathrm{mln}$ ton-days including because of failure of giving vans $-1,6 \mathrm{mln}$ ton-days. In the result of non-fulfilment of plan of giving vans for 1 of January, 1970 the remains of entrepot loads in river ports were 96 thousand tons including in Cherkassy - 39 thousand tons, Zaporizhzhya - 24 thousand tons [2].

But often such switchings were organized without the proper grounding, essentially undermining the further confidence to the mixed transportations. For example, in accordance with the decision of union government in winter period 1978-1979 there was realized an experiment 
on transportation of iron-ore pellets from the Dnipro ore-mining and processing enterprise to the Dnipropetrovsk metallurgical plant named after Dzerginsky. Under severe conditions at minus temperature three motor ships with carrying capacity 1800 tons transported 102 thousand tons of pellets although according to technical-navigational characteristics, navigation was not allowed in nature-climatic conditions of Dnipro basin in winter period [3].

To the objective causes of insufficient switching of loads and introduction of more rational mixed transportations can be referred the absence of economic stimulation of the workers of adjacent transport organizations for the common results of the labor, - and as the result, the absence of unity in plan rates.

The order of organization of container transportations in the regions of republic was built without taking into account the complex operation of the different transport types that led to the irrational use of container fund and low level of container transportations, ineffective use of the different transport types [1].

The speed of loads delivery remained the weak link of transport system of republic, especially at mixed railway-motor or railway-water transportations. The delivery terms during 1965-1975 (at increase of technical speed) were not reduced but increased nearly by $8-10 \%$. The transportation terms in mixed railway-water communication were especially long [14]. In most cases it was conditioned by untimely removal of loads from railway stations, water, sea and airports - junction (cross) points [3].

The existing system of planning and accounting of the work of junction points complicated the further introduction of system organization of management of progressive transportation technology and complex transport-expeditionary service in transport junctions. Nevertheless the different system of planned work rates of adjacent transport enterprises in the points of their junction (railway stations - unloading in vans, mechanized distances of loading-unloading works - ton-operations, transport-expeditionary enterprises - tons, motor transport enterprises - tons and ton$\mathrm{km}$ ) - often generated the mutual interdepartmental complaints, incoherence and contradictions in organization of common work, impeded the introduction of progressive transport technology and complex transport-expeditionary service [10].

Especially serious defect was the disintegration of administrative subordination of junction transport-expeditionary offices and enterprises of the motor transport of Ministry of motor transport of Ukrainian SSR. It was not financially responsible for the derangement of loads removal from railway stations, transferred the responsibility on the junction transport-expeditionary offices. Thus, in 1970 the enterprises of Ministry of motor transport of Ukrainian SSR failed to give for centralized transportations of loads in first shift more than 250 thousand trucks or 15,3\%, in second shift - near 43 thousand trucks. In the same year were not given more than 90 thousand trucks worked with pay by the hour that was near $35 \%$ of approved norm of giving trucks. The big non-productive consumption of both order time at the expense of their delayed coming on the line and early finish of the work took place. In 1970 it was over 510 thousand machine-hours that was equal to the transportation of 1,2 mln tons of load [8].

In general the technical development of junction points of interaction of motor and railway transport provided their complex and relatively coherent operation on centralized base at the level up to $30 \%$ [1]. It was revealed, that it was based on the departmental separation of economic organizations that participated in the process of transferring load from the one transport type to the other [3]. The planning of development of junction points at the level of interconnected volumes of transportations of the different transport types was concentrated in separate departments and usually was not mutually coordinated that led to disproportion in their development with all negative consequences [10].

In 1960 years took place certain changes of organizational structure of motor transport - enterprises were consolidated and transferred on the state account. It favored the introduction of centralized transportations, which part in coast-accounting motor economies in 1964 reached $62 \%$ of the volume of transportations by motor transport of the general use. The central dispatching services were created in several cities [15].

But in general the development of centralized transportations remained insufficient. That is why the series of government decisions was directed on the improvement of the work on orga- 
nization of centralized transportations. Especially for facilitation of supply of collective farms and other state agricultural enterprises, the Ministries Council of USSR 14 of November, 1969 accepted regulation "On the development of centralized transportations in agriculture. This document entrusted the realization of centralized transportation of loads of state agricultural enterprises and organization to the "Union agricultural technique", including their transport-expeditionary service at the railway stations and river wharfs.

In transport enterprises were created motor columns with a number no less than 100 trucks in each one. The union government had a right to throw these motor columns if necessary from the one union republic to the other for harvesting and procurement of agricultural products and inter-republic transportation of them [2].

In July of 1974 the Ministry Council of Ukrainian SSR accepted the directive of "On the arrangements on further widening of centralized transportations of loads by the motor transport", according to which the Ministry of motor transport of Ukrainian SSR received the "method of projecting of unitary technological process" and sent it for carrying out to the regional administrations and associations of motor transport for introducing the new technology of the work at centralized railway stations, river ports, transport-expeditionary and motor transport enterprises. The temporal regulations on the annual, quarterly and month planning of centralized transportations of loads at railway stations and river ports with realization of transport-expeditionary operations by the motor transport of Ukrainian SSR were elaborated, coordinated with State plan and approved [3]. At the same time the Ministry of motor transport together with the Ministry of building materials and State supply elaborated the arrangements that completely centralized the transportations of coal, road-building loads, sugar beet, seed and other mass loads [15].

The centralized transportation of loads in 1975 increased comparing with 1970 by $62 \%$, their specific weight in the general volume of transportation by the motor transport of general use was by tons $79 \%$, and by ton $/ \mathrm{km}-75,1 \%$ [4]. The volume of centralized transportations by the motor transport of general use in 1979 reached 897,3 mln tons. But the tasks were not fulfilled. For example, the specific weight of centralized removal of loads from the metal base № 3 of administration Kharkiv metal supply and sale" of Poltava region was $42,6 \%$ at planned $80 \%$.

The essential defects took place at centralized removal of small consignments in which result the volumes of self-removal of loads from bases and shops of State supply of Ukrainian SSR did not decrease during 1970 years. At the bases took place the long overtime stoppages of rolling stock as the result of unsatisfactory organization of loading-unloading works. In 1979 the penalty for overtime motor stoppages at the bases of State supply was 159 thousand crb only in 14 regions of republic.

In 1979 the plans for enterprises of the Ministry of nonferrous metals of USSR was fulfilled for $96 \%$, State supply of USSR - for $92,9 \%$. The level of execution of centralized transportations of such types of loads as bricks in 1979 was 97,4\%, cement - 97,3\%, petroleum and petroleum products $-98,5 \%[13]$.

In 1980 the CC of CPU fixed the essential defects in trucks usage. The transportations of loads that were economically expedient to realize by the trucks of organization of general use, were carried in significant volumes by the departmental transport that led to the parallelism in the work of motor transport, worsening its technical-economic rates. Coordination of the work on the trucks usage at intercity and central transportations and also on their technical maintenance and repair was absent [5].

\section{Discussion of the results}

The disadvantages of this work are the problems of effective use of historical experience of the development of transport complex of Ukrainian SSR but despite this fact in the work were noted that just coordination of transport, effective and rational use of all capacities are the main components of effective transport development of any country taking into account the modern globalization tendencies. This research is important for both scientists and managers of state power bodies and local self-government. The offered research needs the further elaboration. 


\section{Conclusions}

So, the analysis of the work of transport complex of Ukrainian SSR testifies that in this period the transport branches of republic developed rather dynamically and satisfied the needs of economy and population. But the transport work was negatively influenced by the absence of proper coordination and interaction of the different transport types and departmental incoherence in organization of transportation work. The specific weight of the motor transport of general use remained low, the transport-expeditionary service was imperfect, the volumes of irrational transportations by railway transport decreased slowly. The imperfection of the mechanism of switching of loads transportations from the railway transport to the motor and river one and introduction of more rational mixed transportations was a problem. The proper attention was not paid to the system of economic stimulation of the workers of adjacent transport organization for the common results of labor.

For the strengthening of coordination of transportations, the organizational arrangements, directed on the improvement of the system of management of transport complex, were carried out - in the regions were created transport-expeditionary offices, responsible for the complete service of clients, the motor columns in the system of agricultural enterprises "Agricultural technique" were created for transportation of agricultural loads. But these arrangements did not give the expected results and the problem of coordination and cooperation of the different transport types remained urgent.

\section{References:}

[1] Lysenko, Ju. Ja., Gurnak, V. N. (1986). Transport respubliki v 12 pjatiletke. Kyiv: Tehnika, 199.

[2] Gurnak, V. N. (1986). Transportnyj potik respubliky. Kyiv: Znannya URSR, 49.

[3] Czvetovm, Yu. M.; Shulgin, L. V. (Ed.) (1972). Problemy udoskonalennya koordynaciyi roboty zaliznychnogo i avtomobilnogo transportu v punktah yih vzayemodiyi. Pytannya rozvytku usih vydiv transportu v Ukrayinskij RSR. Kyiv: Derzhplan URSR, 130-141.

[4] Slavov, N. (1982). Na rechnyh magistraljah Ukrainy. Rechnoj transport, 12, 6-7.

[5] Pilipenko, V. A., Kruglov, S. G. Eds. Shul'gin, L. V. (1972). Pitannja rozvitku vnutrishn'ogo vodnogo transportu Ukraïns'koï RSR. Pitannja rozvitku usih vidiv transportu v Ukraïns'kij RSR. Kyiv: Derzhplan URSR, 19-24.

[6] Centralnyj derzhavnyj arhiv vyshhyh organiv vlady ta upravlinnya Ukrayiny. F. 5096, Op. 1, Spr. 453, Ark. 10.

[7] Centralnyj derzhavnyj arhiv gromadskyh ob'yednan Ukrayiny. F. 1, Op. 25, Spr. 715, Ark. 6-20.

[8] Centralnyj derzhavnyj arhiv gromadskyh ob'yednan Ukrayiny. F. 1, Op. 25, Spr. 1416, Ark. 1-10.

[9] Centralnyj derzhavnyj arhiv gromadskyh ob’yednan Ukrayiny. F. 1, Op. 25, Spr. 2280, Ark. 26-28.

[10] Borisov, N. N. (1985). Kompleksnoe programmnoe sovershenstvovanie vzaimodejstvija raznyh vidov transporta v Ukrainskoj. Kyiv: Znannja, 104.

[11] Centralnyj derzhavnyj arhiv vyshhyh organiv vlady ta upravlinnya Ukrayiny. F. 4949, Op. 16, Spr. 3, Ark. 52-56.

[12] Centralnyj derzhavnyj arhiv vyshhyh organiv vlady ta upravlinnya Ukrayiny. F. 3, Op. 3, Spr. 1594, Ark. 1-14.

[13] Centralnyj derzhavnyj arhiv gromadskyh ob’yednan Ukrayiny. F. 1, Op. 25, Spr. 2121, Ark. 17-23.

[14] Centralnyj derzhavnyj arhiv vyshhyh organiv vlady ta upravlinnya Ukrayiny. F. R 2, Op. 15, Spr. 776, Ark. 15, 21, 80, 82, 110-114, 132.

[15] Nesterenko, O. (Ed.) (1960). Narodne gospodarstvo Ukrayinskoyi RSR u semyrichci. Suchasnyj stan ta perspektyvy rozvytku. Kyiv: Vydavnycztvo Akademiyi Nauk URSR, 519.

[16] Centralnyj derzhavnyj arhiv vyshhyh organiv vlady ta upravlinnya Ukrayiny. F. R2, Op. 14, Spr. 6678, Ark. 3-10, 46-52. 